\title{
Change Management in Information Systems Projects for Public Organizations in Poland
}

\author{
Ewa Ziemba and Iwona Obłąk \\ University of Economics, Katowice, Poland
}

\author{
ewa.ziemba@ue.katowice.pl iwona.oblak@ue.katowice.pl
}

\begin{abstract}
It can be argued that public organizations, in order to provide the public with sufficient services in the current, highly competitive and continuously evolving environment, require changes. The changes that become necessary are often related to the implementation of information systems (IS). Moreover, when organizations are faced with changes, a change management (CM) process needs to be put in place. CM theories that are currently available to practitioners and academics are often contradictory; they mostly lack empirical evidence and are supported by unchallenged hypotheses concerning the nature of the contemporary $\mathrm{CM}$. The aim of this paper is, therefore, to identify critical success factors (CFSs) for CM in IS projects. In order to reach this aim an explanation of changes in public organizations and the nature of $\mathrm{CM}$ are presented. Following this, a framework of CFSs for CM in IS projects are identified based on the literature review. The paper also examines two IS projects and uses them to demonstrate CFSs influencing CM in IS projects in Polish pubic organizations. A discussion of the research findings is provided and the paper concludes with a presentation of the study's contributions and limitations as well as the stream of future work.
\end{abstract}

Keywords: project management, change management, public organizations, information systems, IS, critical success factors, CSF

\section{Introduction}

Currently, public organizations are often confronted with the need to implement changes to existing processes. This need is often connected with transformation that takes place in public management and the implementation of information systems (IS) (Boyne, Farrell, Law, Powell, \& Walker, 2003; Kickert, 2007; Ongaro, 2010; Pollitt \& Bouckaert, 2011). The literature provides various examples of failure of large and complex IS projects (Goldfinch, 2007; Loukis \& Charalabidis, 2011), and in many cases, the reason for IS implementation failure is a lack of change management (CM) (Aladwani, 2001; Momoh, Roy, \& Shehab, 2010; Somers \& Nelson, 2001;

Material published as part of this publication, either on-line or in print, is copyrighted by the Informing Science Institute. Permission to make digital or paper copy of part or all of these works for personal or classroom use is granted without fee provided that the copies are not made or distributed for profit or commercial advantage AND that copies 1) bear this notice in full and 2) give the full citation on the first page. It is permissible to abstract these works so long as credit is given. To copy in all other cases or to republish or to post on a server or to redistribute to lists requires specific permission and payment of a fee. Contact Publisher@InformingScience.org to request redistribution permission.
Umble, Haft, \& Umble, 2003). CM provides a solution to two major problems: how to plan better for the implementation of changes and how to overcome employee resistance (Anderson \& Anderson, 2001) to these changes. CM refers to a set of basic tools or structures intended to keep any change effort under control (Hornstein, 2014). 
Traditionally, the theory of CM has been based on research cases for business organizations (Stewart \& Kringas, 2003; Thomas, 1996). The prior studies on CM did not concentrate on the specific contextual characteristics of public organizations (Kuipers et al., 2014). However, an interest in CM in public organizations has been noted (Fernandez \& Pitts, 2007; Fernandez \& Rainey, 2006). Recent studies have questioned the fact that CM techniques for the private sector are applicable in the public organization context and have suggested that the differences between the public and private sector could play a significant role in this respect (Boyne, 2006; Karp \& Helgø, 2008; Kickert, 2013; Klarner, Probst, \& Soparnot, 2008; Rusaw, 2007). Roughly they involve different environmental, organizational, and process related factors (Caudle, Gorr, \& Newcomer, 1991). Several authors have suggested that the specific context of public organizations may have consequences for $\mathrm{CM}$, but there is little empirical evidence concerning this issue. A recent literature review of research on CM in the public sector by Kuipers et al. (2014) found that most studies emphasize the content and context of change, instead of the implementation process. Moreover, researchers conclude that many studies did not address the outcomes or success of a change intervention.

Ubiquitous information systems and implementation of various kinds of changes related with IS adoption have become a challenge for public organizations (Jääskeläinen \& Sillanpää, 2013). Public organizations' efforts relate to a successful IS and CM implementation, experiencing various conditions and are connected with a substantial risk of failure. The considerations of IS and CM implementation may be expressed as critical success factors (CSFs) (Rockart, 1979). CSFs represent the limited number of areas of activity in which the achievement of satisfactory results will ensure the success of IS projects in public organizations, also activities associated with CM.

However, the processes through which the change in public organizations comes about are not described in detail in the literature (Kickert, 2010; Kuipers et al., 2014). The existing research work mostly examines CM in IS projects in business organizations only. The authors of this paper, after extensively searching the literature, could not find any significant studies concerning applying CM in IS projects in public organizations. This portrays the need for studying how CM should be used in IS projects in public organizations and how it affects the success of these projects. This research hold the promise that conducting research among Polish public organizations should contribute to greater understanding of the use of CM in IS projects and should help fill the gap in the existing body of knowledge.

In light of the above limitations, the objective of this study is to identify CSFs for CM in IS projects in Polish public organizations. To reach this objective, an explanation of CM is offered, especially in the context of IS projects. A literature review is conducted with specific focus on CSFs for CM. Next, two IS projects in public organizations in Poland are presented, the employment of CM in these projects is shown and the CSFs for those CM in the projects are identified, and a discussion of the research findings is provided. This paper concludes with a presentation of the study's contributions and limitations, and the stream of future works that may arise.

\section{Literature Review}

\section{Changes Driven by Projects}

The literature review strongly suggests that change is an inevitable consequence of implementing various projects (Hornstein, 2014; Serra \& Kunc, 2014). A project is a temporary and unique group of activities with the beginning and end in time clearly mapped out and designed to accomplish defined goals (PMI, 2013). Although project management (PM) and CM are derived from different terminologies and different methodologies (Hornstein, 2014), they are, nevertheless, 
tightly linked and co-dependent. They also emphasize different sets of skills and competencies (Crawford, \& Hassner-Nahmias, 2010).

According to the Project Management Institute (PMI), PM is the application of knowledge, skills, tools, and techniques to project activities to meet project requirements. It is accomplished through the application and integration of PM processes such as initiating, planning, executing, monitoring and controlling, and closing (PMI, 2013). PM is the disciplined application of knowledge, skills, tools and techniques to project activities to meet the project requirements (PMI, 2013; Turner \& Müller, 2005).

$\mathrm{CM}$ is the process, tools, and techniques to manage the people-side of change to achieve the required business outcome. CM incorporates the organizational tools that can be utilized to help individuals make successful personal transitions resulting in the adoption and realization of change (By, 2005). CM contributes to the successful implementation of a wide variety of projects. Not only does project success utilize the traditional measures of project performance but it is also associated with change management (Crawford, Aitken, \& Hassner-Nahmias, 2014). Both $\mathrm{PM}$ and CM support moving an organization from a current state through a transition state to a desired future state (Lewin, 1947). PM focuses on the tasks to achieve the project requirements. $\mathrm{CM}$ focuses on the people impacted by the change.

$\mathrm{CM}$ in the context of PM can be examined from two perspectives. The first one describes changes occurring in the project itself, e.g., a change of a project goal or its scope. Each addition or deletion to project goals or to project scope is considered to be a change, whether it increases or decreases the project cost, schedule, or quality (Ibbs, Wong, \& Kwak, 2001). In PM context, CM may refer to a PM process wherein changes to the scope of a project are formally introduced and approved. In this context change management in a project is seen as a creation of procedures that enable the implementation and acceptance of changes to the project itself. The other perspective refers to changes which have to be implemented in public organizations before or during implementation of IS projects, e.g., an introduction of a new IS will require changes to procedures or workflow. This paper focuses on CM in this very context, i.e., changes that result from the implementation of IS.

\section{Change Management in Information System Projects}

Change management is a process that helps organizations in the implementation of an appropriately planned change (Beekman, Chenhall, \& Euske, 2007; Nutt, 1992; Tan \& Tan, 2005). CM in the context of IS projects is understood as activities, processes, and methodologies that support employee understanding and organizational aspects during the IS projects (Al-Mudimigh, Zairi, \& Al-Mashari, 2001). CM refers to all activities associated with the interaction of technology, processes, and people (Harris, 1999). Academic research has shown that it is not the technology that provides an organization with a success, but the integration of technology into an organizational change management process (Hornstein, 2008). This approach takes into account the importance of people in an organization.

A successful IS project requires, among other things, a human resource strategy to improve the necessary employee skills and their engagement in the process of CM (Hornstein, 2014). Moreover, IS project very often requires reorganization of processes in operation at this point of time. In turn, reorganization of processes is strictly connected with a need to implement the CM concept (Hornstein, 2008; Suman, Ursic, Psunder, \& Veselinovic, 2009). Some authors, who also consider public sector changes, point at the fact that these changes may not be more difficult than those in the private sector, but for sure they are different (Cunningham \& Kempling, 2009). It can even be stated that CM is a key to success of public organizations IS projects (Higgins, 2005; Umble et al., 2003). 
The literature on project success factors has been relatively quiet about the role of change (Turner \& Müller, 2005). In addition, PMI, for example, which offers training on project management, does not account for changes brought along with the project. Various practical reports, e.g., The Economist (2009) and PWC (2007), and academic studies suggest that practitioners recognize projects as a structured way to implement business changes (Buttrick, 1997; Kerzner, 2013; Turner, 2009). Nonetheless, CM has continued to have a relatively small representation in the project management literature.

\section{Critical Success Factors for Change Management in Information System Projects}

In the literature there are several definitions of CSFs. Leidecker and Bruno (1984) described CSFs as a set of characteristics, conditions and variables which should be adequately sustained, maintained, or managed in order to affect success factors of an organization competing in a specific industry (Leidecker \& Bruno, 1984). Rockart and Bullen (1981) defined the CSFs as the restricted number of fields in which positive outcome will result in "successful competitive performance" for employees, organizational units, and an organization as a whole. According to Ramaprasad and Williams (1998), the CSFs should be used in three crucial areas including PM, information systems implementation, and requirements.

CSFs for CM in IS projects have not been much explored in the literature. There are many authors describing CSFs for CM (Averweg \& Erwin, 1999; Graetz, 2000; Guimaraes, Igbaria, \& Lu, 1992; Hotek \& White, 1999; Palvia \& Chervany, 1995; Rothwell \& Kazanas, 1998; Underwood-Stephens \& Cobb, 1999; Weber \& Weber, 2001). However, there are not too many describing CSFs for CM in IS projects.

For the purpose of this study, the CSFs for CM in IS projects have been identified based on the literature review (Table 1). The framework includes CSFs for CM, which are described in the literature on CM, and, moreover, only those that may refer to CM in IS projects have been selected. Further, CSFs defined by particular authors have been analyzed, classified, and unified. The identification of these key factors also allows for measuring the influence of CM on IS project. The authors state the assumption that all factors are equally important and none of them has been prioritized.

Table 1: Critical success factors for change management in IS projects

\begin{tabular}{|l|l|}
\hline \multicolumn{1}{|c|}{ CSFs } & \multicolumn{1}{|c|}{ Definition } \\
\hline 1. Top management support & $\begin{array}{l}\text { Active and visible support from a management team. } \\
\text { Involvement and commitment of senior management. } \\
\text { Direct participation of the strategic decision makers in an IS project. }\end{array}$ \\
\hline 2. Recognize the change & $\begin{array}{l}\text { The need for change has to be established } \\
\text { Promote a positive approach to change }\end{array}$ \\
\hline 3. Shared vision for change & The vision should be strongly advocated across the organization \\
\hline 4. Planning a project as a change & $\begin{array}{l}\text { Evaluation of the gap between where the organization is now and } \\
\text { where it would like to be } \\
\text { Manage entire change process as a project } \\
\text { Prepare a change management plan } \\
\text { Promote change in the organization }\end{array}$ \\
\hline 5. Managerial activity & $\begin{array}{l}\text { Involvement of managers who are directly associated with the change } \\
\text { process }\end{array}$ \\
\hline
\end{tabular}




\begin{tabular}{|c|c|}
\hline CSFs & Definition \\
\hline 6. Effective communication & $\begin{array}{l}\text { Communicate the change message at all levels throughout the organi- } \\
\text { zation }\end{array}$ \\
\hline $\begin{array}{l}\text { 7. Organization readiness to deal chang- } \\
\text { es }\end{array}$ & $\begin{array}{l}\text { Organization needs to be ready to deal with change } \\
\text { Employees need to feel that the organization is ready to deal with } \\
\text { change }\end{array}$ \\
\hline 8. Employees training & Clear demonstration how to use IS \\
\hline 9. Employees involvement & $\begin{array}{l}\text { Belief the employees that the change is important and has impact on } \\
\text { the organization's success }\end{array}$ \\
\hline 10. Employees satisfaction & Satisfaction with the final product and its acceptability by employees. \\
\hline 11. Information flow & $\begin{array}{l}\text { Having readily available and current data gathered in one place and } \\
\text { available to all interested }\end{array}$ \\
\hline 12. Performance measurement & $\begin{array}{l}\text { Measure of change performance and value it to employees to demon- } \\
\text { strate success }\end{array}$ \\
\hline
\end{tabular}

Sources: (Aladwani, 2001; Chrusciel \& Field, 2006; Cocks, 2014; Davenport, Harris, \& Cantrell, 2004; Graetz, 2000; Guimaraes et al., 1992; Hotek \& White, 1999; Sutanto, Kankanhalli, Tay, Raman, \& Tan, 2008; Weber \& Weber, 2001).

The following paragraphs present a more comprehensive explanation of each of the CSFs presented in Table 1.

Top management support. Top management support helps formulate and establish quality policies and objectives, provides resources and training, oversees IS implementation at all levels of the organization, and evaluates and revises the policy in light of results achieved (Chrusciel \& Field, 2006; Sutanto et al., 2008).

Recognize the change. Recognizing the change helps understand what exactly will be changed and whom the change will affect (Graetz, 2000). The change needs to be defined clearly. The appropriate identification of changes determines changes in organization's processes and the employee's tasks and responsibilities. As a result, it sets a direction of organization's development.

Shared vision for change. Shared vision for change is important to direct the system change effort and to serve as a foundation from which specific strategies need to be developed for arriving at a future end-state (Sutanto et al., 2008). The change agents must ensure that the organizational stakeholders understand the vision of how the IS will be able to transform the organization. It is very important to have a clear vision and objectives for organizational success, especially during times of increased uncertainty, such as a change process (Weber \& Weber, 2001). It is also very important to understand the current state of the organization that can be viewed as the platform from which the CM plan will launch (Cocks, 2014).

Planning a project. Planning a project as a change involves managing human and other resources. A clearly documented change management process helps make a map of the tasks and resources required (Cocks, 2014).

Managerial activity. Commitment of line managers to CM creates a situation that they identify with a change. They also manage the time of their subordinates accordingly, accounting for their involvement in change processes in their assignments (Chrusciel \& Field, 2006).

Effective communication. Effective communication is crucial for effective CM. Without proper communication, the employees involved in the change process would not know what changes were made, what changes are being made, what changes should be made. Moreover, the employees would not be aware of their tasks related to the implemented changes. Communicating the 
message repeatedly up, down, and across the organization is necessary to ensure that the momentum and enthusiasm for change does not diminish over time (Graetz, 2000). Communication by top management is seen as a powerful leverage in gaining commitment and building consensus about the required change (Kotter, 1995).

Organization readiness to deal changes. This factor reflects employees' perceptions of the extent to which an organization is ready to make changes to improve performance (Weber \& Weber, 2001). Dealing with a change helps provide better understanding of forthcoming changes by employees.

Employees training. Employees' training was identified as important, but it is very subjective in nature (Chrusciel \& Field, 2006). Employees' training is a clear demonstration of how to use the IS. After conducting training, employees will gain initial experience with the change, and as a result the initiative will bear an impact on them; they may demonstrate greater understanding and support for management and the planned change effort (Weber \& Weber, 2001).

Employees involvement. Employees' involvement is very important in CM success. Employees' involvement is the degree to which employees participate in the improvement activities. By engaging employees in the change processes, they identify more with the success. Employees' participation is a degree to which employees believe they can make decisions about how they perform their tasks and work (Weber \& Weber, 2001).

Employees satisfaction. Employees' satisfaction is the precondition for successful change implementation connected with IS projects. Satisfaction is not fully felt until the employees get used to a new IS. At the beginning, there is always a noticeable resistance to change (Smith, 2005). Thanks to the training of employees, the resistance can be quickly overcome. Moreover, the enhancement of information flow on changes diminishes the resistance.

Information flow. Organizations improve their ability to be informed about running a project by providing better access to data (Davenport et al., 2004). Not only should organizations provide access to data, but the available data should be consistent, timely, and accurate. Besides there should be information sent if any changes in data occurred.

Performance measurement. Performance measurement is a critical factor for the success of IS projects (Feurer \& Chaharbaghi, 1995; Greiling, 2005). Implementation progress must be measured regularly for more efficient and effective control. Through monitoring and feedback from the users, the performance of the change process can be reviewed and evaluated to see whether it is achieving business goals and objectives.

The literature lacks proven scientific theories and experience on the impact of CM on IS projects in public organizations. Hence, providing CSFs for CM in IS projects in public organizations is becoming an important task. The starting point of defining CSFs for public organizations should be those critical factors already identified for private organizations. The literature provides examples of adapting these factors in public organizations. Most of those factors are the same for the private and public organizations (Caudle et al., 1991; Indeje \& Qin, 2011).

\section{Research Methodology}

The goal of our research was to indicate CSFs for CM in IS projects in public organizations. In order to achieve the goal, various scientific methods and techniques have been applied, especially a critical analysis of the literature and case studies as well as methods of creative thinking and logical deduction.

To explain the nature of CM and identify CSFs for CM in IS projects, a critical analysis of the literature as well as methods of creative thinking and logical deduction have been used. In order 
to present the practical dimension of CM in IS projects in public organizations, a case study approach has been applied. Semi-structured interviews of end-users and project team members were conducted, as well as shareable documentations related to IS projects management were analyzed for the case studies. We also used our extensive practical experience of IS projects and of CM in those projects to guide the research.

The studies related to the IS projects in public organizations and CSFs for CM in those projects were conducted in 2010 and 2013. This involved IS projects in two Polish public organizations projects included development and implementation of integrated IS.

\section{Research Findings}

\section{Case Studies of Information System Projects}

Public administration in Poland, due to the territorial scope of its operations, is divided into public organizations at the state level embracing the whole of Poland and public organizations at local levels embracing voivodeships (provinces) and districts. The case studies of IS projects considered below refer to the state level, where the project management took place, and the local levels, where the two IS projects were implemented.

The two similar projects, one successful and one not successful, will be used to present the application of CM in IS projects. Information about each project was gathered by participation in those projects and conducting a series of semi-structured interviews. Table 2 shows that the two projects were similar in terms of scope and size, but $\mathrm{CM}$ was only used in project $\mathrm{B}$. As a result, the outcomes of the projects were different. Project A ended only as a partial success. Although the IS was finally implemented, it was not fully used by end users after 12 months. The completion of project A was also significantly delayed. Project B was fully successful. The IS was implemented and it is fully used by its end-users.

\begin{tabular}{|l|l|l|}
\hline \multicolumn{3}{|c|}{ Table 2: Project A and B - comparison of basic variables } \\
\hline \multicolumn{1}{|c|}{ Features } & \multicolumn{1}{|c|}{ Project A } & \multicolumn{1}{c|}{ Project B } \\
\hline Project type & Information system & Information system \\
\hline Sector & Public administrations & Public administrations \\
\hline Initial schedule & 12 months & 18 months \\
\hline Budget & Realistic & Realistic \\
\hline Success criteria & $\begin{array}{l}\text { On time, within budget, successful } \\
\text { installation of ERP system }\end{array}$ & $\begin{array}{l}\text { On time, within budget, successful installation } \\
\text { of web-based information system }\end{array}$ \\
\hline IS software & Custom made & Custom made \\
\hline End-users & Public organization employees & $\begin{array}{l}\text { General public, } \\
\text { Public organizations employees }\end{array}$ \\
\hline No of end-users & 400 & 35 000 \\
\hline $\begin{array}{l}\text { Project manage- } \\
\text { ment methodolo- } \\
\text { gy }\end{array}$ & $\begin{array}{l}\text { PRINCE2 } \\
\text { (only few basic documents where cre- } \\
\text { ated) }\end{array}$ & $\begin{array}{l}\text { PRINCE2 } \\
\text { (full documentation needed were created) }\end{array}$ \\
\hline $\begin{array}{l}\text { Change manage- } \\
\text { ment }\end{array}$ & No (changes were introduced ad hoc) & Yes \\
\hline $\begin{array}{l}\text { Project result after } \\
12 \text { months }\end{array}$ & $\begin{array}{l}\text { Software was made but not fully used } \\
\text { after 12 months }\end{array}$ & $\begin{array}{l}\text { Software was made and fully used after 12 } \\
\text { months }\end{array}$ \\
\hline
\end{tabular}


Project A was carried by a public organization at the state level. The aim of the project was to improve and automate government processes and to implement an integrated information system, i.e., an ERP system in sixteen public organizations at the local levels. The ERP system used until this point in time was out of date. The objectives of change were to centralize the management of the organizational structure of all sixteen public organizations and the automation of supporting government processes for finance and accounting, human resources management, payroll management, inventory management, and fixed assets management. The expected benefits of the project (and the change) were to eliminate unnecessary documentation, systemize document circulation, ensure a smooth flow of information, and make information accessible (which is relevant and timely to appropriate users and in an appropriate form). A dedicated project team of the central public organizations was responsible for the implementation of the ERP system. It was composed of IT and government specialists, especially employees from the departments of the central public organization, such as: accounting, human resources, payroll, fixed assets, and inventory management, and from the IT department. Moreover, the project team was supported by people from the IT company specializing in the implementation of ERP systems for public organizations, especially business analysts, systems analysts, and project team leaders.

Project A was managed using PRINCE2 methodology; however, only a few documents were created. There were no documents devoted to risk management and change management. The project team was not fully involved in the project. This meant that the people were not permanently assigned to the project, but involved as needs arose. The particular project members were not clearly acquainted with their role in the project. Neither were they informed about the necessity of new IS implementation, nor about the main goal of IS project. The project team was not always informed about the project status. Moreover, a proper system analysis process was omitted. The end-users did not have the opportunity to express their needs and expectations towards IS. This caused that the all project team members had a negative attitude to the project and approached the implemented change reluctantly. They were strongly opposed to the forthcoming changes and wanted to postpone them. The system end-users, who were not the members of the project team, also were not informed about the IS change. The change was authoritatively imposed upon them by their superiors just before the project implementation. As a result, the implementation of the system was extended. This was caused by the lack of coherent schedule that would have coordinated the IS implementation in sixteen public organizations.

Project B was also carried out by a public organization at the state level. The aim of the project was to implement IS for supporting processes of service provision for citizens. As a result of the project the following types of IS were implemented: integration platform, business intelligence, enterprise portal, web based information portal, and mobile terminal software. The project was undertaken as a consequence of the diagnosed problems arising from the lack of IT system integration. The lack of integration made it impossible to have quick access to information indispensible for effective functioning and monitoring of operations of public organizations and caused an ineffective flow of information between the public organizations and the cooperating institutions. The lack of system cooperation compounded the difficulties in monitoring funds allocation and expenditure and the difficulties in monitoring the use of funds by individual public organizations.

Project B was managed using PRINCE2 methodology, where all necessary documents essential for effective project management were created. The project team was formally established. Particular people were permanently assigned to particular parts of the project. The scope of their responsibilities was explicitly defined. The project team consisted of an IT specialist group and a government group made up of specialists who were the main users of the system. Change management was conducted concurrent with the project implementation. The end-users participated in a series of conferences where a clearly defined project goal and successively accomplished tasks were presented. Moreover, they actively participated in system analysis meetings where they de- 
fined the system requirements. The project had a coherently worked-out schedule that also included a project team meeting schedule. The project team was kept informed about the project progress and participated in the final IS testing.

\section{Change Management in Information System Projects}

As mentioned, CM was not tested in project $\mathrm{A}$, and the necessary changes were implemented ad hoc, whereas CM was applied to project B in a methodologically correct manner. Table 3 shows the CM evaluation for the two IS projects in the relation to the CSFs identified in Table 1.

Based on the examination of the case studies, the authors can draw the same observations. Obviously, it can be stated that in case of project A, where only 2 of 12 CSFs listed were met, the lack of CM could have contributed to the failure of IS project. Finally, IS was created and implemented with a significant delay. Besides, within 12 months after having completed the implementation, the users did not take advantage of the IS's full capacity. In case of project B, 11 out of 12 CSFs were met. It can be assumed that those factors played a significant role in the IS project's success. Project B was completed on schedule.

\section{Effect of Change Management on Information System Projects Success}

The study investigated two projects, one successful and one not successful. The fact that the successful one implemented CM and the unsuccessful one did not, in itself is not proof that implementing CM will guarantee success. However it is worth considering that implementing CM can contribute to the project success. The research was based on two case studies and the reports published by the project managers in both cases. Although these sources primarily reflect personal views, it should be stated that project managers and whole project teams are valuable sources of knowledge on IS projects, also in terms of their success or failure. CSFs analyzed in the paper are also considered as preconditions for CM success by other researchers. This demonstrates that the factors described in this paper may accurately reflect the state of practice of CM in IS projects.

As the presented case studies showed, the application of CM bore an influence on the IS project success, though, it should be kept in mind that project success and CM success are different terms. A project success is measured against a project's overall achievement of the project's objectives (Cooke-Davies 2002; De Wit, 1988; Drury-Grogan, 2014). PM success is mostly based on budget, schedule, and requirements goals (Cooke-Davies, 2002; Serrador, 2013). CM success reflects the implementation and acceptance of change by people. IS project success depends on two variables, namely. sound project management and CM application. At the same time, it is worth stressing that CM mainly focuses on human factors.

The involvement of top management and line managers in the change process is as important as the involvement of end-users whom the changes concern most. The careful mapping out of the change process and its further consistent implementation are key success factors too. The continuous flow of information during a project is also of high importance, especially the flow of information from managers on specific successive steps of the change as well as the feedback from end-users on the evaluation of the implemented change. 
Table 3: CM evaluation for Project A and Project B

\begin{tabular}{|c|c|c|c|c|}
\hline $\begin{array}{l}\text { Change man- } \\
\text { agement CSFs }\end{array}$ & & Project A & & Project B \\
\hline $\begin{array}{l}\text { 1. Top manage- } \\
\text { ment support }\end{array}$ & - & $\begin{array}{l}\text { Top management not fully aware of the } \\
\text { complexity of IT project } \\
\text { Steering committee formed - but meets } \\
\text { infrequently } \\
\text { Support of top management not visible }\end{array}$ & $\checkmark$ & $\begin{array}{l}\text { Top management fully aware of the } \\
\text { complexity of IT project } \\
\text { Steering committee meets regularly } \\
\text { Visible top management support }\end{array}$ \\
\hline $\begin{array}{l}\text { 2. Recognize the } \\
\text { change }\end{array}$ & - & Need for change has not been established & $\checkmark$ & Need for change has been established \\
\hline $\begin{array}{l}\text { 3. Shared vision } \\
\text { for change }\end{array}$ & - & No vision of change & $\checkmark$ & $\begin{array}{l}\text { Vision of change regularly promoted } \\
\text { on the meeting with employees at vari- } \\
\text { ous levels of the organization }\end{array}$ \\
\hline $\begin{array}{l}\text { 4. Planning a } \\
\text { project as a } \\
\text { change }\end{array}$ & - & $\begin{array}{l}\text { Project was not planned as a change pro- } \\
\text { cess }\end{array}$ & - & $\begin{array}{l}\text { Project was not planned as a change } \\
\text { process, however there was awareness } \\
\text { of the need for change }\end{array}$ \\
\hline $\begin{array}{l}\text { 5. Managerial } \\
\text { activity }\end{array}$ & $\checkmark$ & $\begin{array}{l}\text { Managers associated with the change pro- } \\
\text { cess were involved }\end{array}$ & $\checkmark$ & $\begin{array}{l}\text { Managers associated with the change } \\
\text { process were involved }\end{array}$ \\
\hline $\begin{array}{l}\text { 6. Effective } \\
\text { communication }\end{array}$ & - & $\begin{array}{l}\text { Communication was not sufficient } \\
\text { End-users were not involved in the change } \\
\text { process } \\
\text { End-users were not informed about the } \\
\text { change }\end{array}$ & $\checkmark$ & $\begin{array}{l}\text { Communication was sufficient } \\
\text { End-users were involved in the change } \\
\text { process } \\
\text { End-users were informed about the } \\
\text { change }\end{array}$ \\
\hline $\begin{array}{l}\text { 7. Organization } \\
\text { readiness to deal } \\
\text { change }\end{array}$ & - & $\begin{array}{l}\text { Change was not clarified to employees } \\
\text { Dedicated user teams were not created to } \\
\text { define and implement IS }\end{array}$ & $\checkmark$ & $\begin{array}{l}\text { Change was clarified to employees } \\
\text { Dedicated user teams were created to } \\
\text { define and implement IS }\end{array}$ \\
\hline $\begin{array}{l}\text { 8. Employees } \\
\text { training }\end{array}$ & $\checkmark$ & $\begin{array}{l}\text { Group of employees has been trained in the } \\
\text { use of IS }\end{array}$ & $\checkmark$ & $\begin{array}{l}\text { Employees were trained in project } \\
\text { management methodology } \\
\text { Group of employees has been trained in } \\
\text { the use of IS }\end{array}$ \\
\hline $\begin{array}{l}\text { 9. Employees } \\
\text { involvement }\end{array}$ & - & $\begin{array}{l}\text { Employees were not involved in the change } \\
\text { process } \\
\text { Very low level of user acceptance }\end{array}$ & $\checkmark$ & $\begin{array}{l}\text { Employees were involved in the change } \\
\text { process } \\
\text { Group of interest was created and em- } \\
\text { ployees were involved in requirement } \\
\text { gathering }\end{array}$ \\
\hline $\begin{array}{l}\text { 10. Employees } \\
\text { satisfaction }\end{array}$ & - & $\begin{array}{l}\text { Very low level of user acceptance } \\
\text { User dissatisfaction manifested }\end{array}$ & $\checkmark$ & $\begin{array}{l}\text { Users start to see value in } \\
\text { integrated systems }\end{array}$ \\
\hline $\begin{array}{l}\text { 11. Information } \\
\text { flow }\end{array}$ & - & $\begin{array}{l}\text { There was not information source Neither } \\
\text { were the participants of the project in- } \\
\text { formed, nor information was provided out- } \\
\text { side about the project performance }\end{array}$ & $\checkmark$ & $\begin{array}{l}\text { There was created information source } \\
\text { There was created document repository } \\
\text { Updates about project were sent to end- } \\
\text { users }\end{array}$ \\
\hline $\begin{array}{l}\text { 12. Performance } \\
\text { measurement }\end{array}$ & - & Performance was not measured & $\checkmark$ & $\begin{array}{l}\text { Performance was measured, and pro- } \\
\text { gress of the project was indicated }\end{array}$ \\
\hline Counts of yes & & $2 / 12=17 \%$ & & $11 / 12=92 \%$ \\
\hline Results & & $\begin{array}{l}\text { - Project was accomplished with a signif- } \\
\text { icant delay } \\
\text { - IS has been implemented, but after } 12 \\
\text { months passing from the implementa- } \\
\text { tion it is not used at its full capacity by } \\
\text { the end-users }\end{array}$ & & $\begin{array}{l}\text { - Project was accomplished on } \\
\text { schedule } \\
\text { - IS has been implemented and it is } \\
\text { used at its full capacity by the end- } \\
\text { users }\end{array}$ \\
\hline
\end{tabular}


Project A did not have the flow of information. Firstly, the top management was not kept informed about the state of project implementation, the barriers encountered, or the risk threat. Secondly, the end-users were not aware of the fact that the IS they were using would, in a short period of time, be changed and that they would have to start working with a new IS. Only the line managers were informed and involved in the change. Despite the fact that they showed a proactive and positive attitude to the forthcoming change, there was a lack of top-down process coordination. In some fields work on the project was completed quickly and efficiently, whereas in others, due to the lack of current information, the accomplishment of specific tasks took longer. All this had negative influence over the whole IS project.

A methodological approach to the change was applied in project B. Relevant information, which was passed to the top management on a regular basis and also to the end-users, was taken care of. Regular conferences were organized for the end-users, where the state of project implementation was presented and the subsequent IS project stages for the nearest period of time were indicated. The end-users were informed about the scheduled date of system implementation and how their previous work would change. The changes made the work even more efficient and accounted for the needs raised by the employees.

To summarize, the result of the case studies may be used to indicate that an IS project will be much more successful if CM methodology is used and defined CSFs are met. This in turn means that public organizations and their managers should pay closer attention to integrating the IS PM with CM. Although, one should always bear in mind that CM success depends on PM success.

\section{Conclusion}

This study contributes to the research of CM in IS projects in two ways. Firstly, the identification of CSFs for CM in IS project was made. Twelve CSFs have been identified, namely: (1) top management support, (2) the change recognition, (3) shared vision for the change, (4) planning a project as a change, (5) managerial activity, (6) effective communication, (7) organization readiness to deal with the change, (8) employees' training, (9) employees' involvement, (10) employees' satisfaction, (11) information flow, (12) performance measurement. Secondly, it showed practical issues concerning those identified CSFs and, consequently, the effect of CM on IS project success.

This study suggested that the relation between CM and IS projects is one of the important determinants of a successful IS project. On the one hand, the timely and effectively managed an IS project is optimized by CM. On the other, a change is an inevitable consequence of IS project implementations.

Although the identified CSFs for CM in IS projects and its practical implementation are generic and comprehensive, a limitation of this study lies in the fact that it is based on only two case studies, which examines only Polish public organizations. The replication of this study for a greater number of IS projects in public organizations in Poland will be useful to enrich the body of knowledge related to the factors bearing an impact on CM in IS projects.

Furthermore, this research can be useful for other Central and Eastern European countries as these countries are similar in many aspects. Their similarity concerns their analogous geopolitical situation and their joint history, traditions, culture, and values. In addition, the similarity reflects in building democratic state structures and a free-market economy, participating in the European integration process, the levels of information systems implementation in public organizations. In addition, they have to resolve the same problems and overcome the same political, economic, social, and technological obstacles in their transition from a traditional government to a government based on information systems. In this research government units and government authorities 
could find knowledge related to the factors impacting on successful information systems projects in public organizations.

Moreover, the issues of CFSs of CM in IS projects in public organizations should be explored in greater depth. There is a need to conduct research, especially into (1) improvement of processes in public organizations after change implementation and (2) exploration of 'best practices' to be used to manage IS projects successfully. This will be considered as future work.

\section{Acknowledgement}

This research has been supported by a grant entitled "Designing a system approach to sustainable development of the information society - on the example of Poland" from the National Science Centre in Poland, 2011/01/B/HS4/00974, 2011-2015.

\section{References}

Aladwani, A. M. (2001). Change management strategies for successful ERP implementation. Business Process Management Journal, 7(3), 266-75.

Al-Mudimigh, A., Zairi, M., \& Al-Mashari, M. (2001). ERP software implementation: An integrative framework. European Journal of Information Systems, 10, 216-226.

Anderson, D., \& Anderson, L. A. (2001). Beyond change management: Advanced strategies for today's transformational leaders. San Francisco: Jossey-Bass/Pfeiffer.

Averweg, U. R., \& Erwin, G. J. (1999). Critical success factors for implementation of decision support systems in South Africa. Proceedings of the 32nd Hawaii International Conference on System Sciences.

Beekman, M., Chenhall, R. H., \& Euske, K. J. (2007). Management control systems as a tool for planned organizational change. Cost Management, 21, 15-25.

Boyne, G. A. (2006). Strategies for public service turnaround: Lessons from the private sector? Administration \& Society, 38(3), 365-388.

Boyne, G. A., Farrell, C., Law, J., Powell, M., \& Walker, R. M. (2003). Evaluating public management reform. Buckingham: Open University Press.

Buttrick, R. (1997). The project workout: A toolkit for reaping the rewards from all your business projects (1st ed.). London: Financial Times Management.

By, R. T. (2005). Organisational change management: A critical review. Journal of Change Management, 5(4), 369-380.

Caudle, S. L., Gorr, W. L., \& Newcomer, K. E. (1991). Key information systems management issues for the public sector. MIS Quarterly, 171-188.

Chrusciel, D., \& Field, D. W. (2006). Success factors in dealing with significant change in an organization. Business Process Management Journal, 12(4), 503-516.

Cocks, G. (2014). Optimising pathways for an organisational change management programme. The TQM Journal, 26(1), 88-97.

Cooke-Davies, T. (2002). The 'real' success factors on projects. International Journal of Project Management, 20, 185-190.

Crawford, L., Aitken, A., \& Hassner-Nahmias, A. (2014). Project management and organizational change. Pennsylvania: Project Management Institute.

Crawford, L., \& Hassner-Nahmias, A. H. (2010). Competencies for managing change. International Journal of Project Management, 28(4), 405-412.

Cunningham, B. J., \& Kempling, J. S. (2009). Implementing change in public sector organizations. Management Decision, 47(2), 330-344. 
Davenport, T. H., Harris, J. G., \& Cantrell, S. (2004). Enterprise systems and ongoing process change. Business Process Management Journal, 10(1), 16-26

De Wit, A. (1988). Measurement of project success. International Journal of Project Management, 6, 164170.

Drury-Grogan, M. L. (2014). Performance on agile teams: Relating iteration objectives and critical decisions to project management success factors. Information and Software Technology, 56(5), 506-515.

Fernandez, S., \& Pitts, D. W. (2007). Under what conditions do public managers favor and pursue organizational change? The American Review of Public Administration, 37(3), 324-341.

Fernandez, S., \& Rainey, H. G. (2006). Managing successful organizational change in the public sector: An agenda for research and practice. Public Administration Review, 66(2), 168-176.

Feurer, R., \& Chaharbaghi, K. (1995). Performance measurement in strategic change. Benchmarking for Quality Management \& Technology, 2(2), 64-83.

Goldfinch, S. (2007). Pessimism, computer failure, and information systems development in the public sector. Public Administration Review, 67(5), 917-929.

Graetz, F. (2000). Strategic change leadership. Management Decision, 38(8), 550-64.

Greiling, D. (2005). Performance measurement in the public sector: The German experience. International Journal of Productivity and Performance Management, 54(7), 551-567.

Guimaraes, T., Igbaria, M., \& Lu, M. (1992). The determinants of DSS success: An integrated model. Decision Sciences, March/April, 409-429.

Harris, J. (1999). Designing change management strategies for ERP systems: Observations from Alameda County, California. Government Finance Review, 15(4), 29-31.

Higgins, J. (2005). Change management is key to public sector IT success. Computer Weekly, 8/30/2005, 33.

Hornstein, H. A. (2008). Using a change management approach to implement IT programs. Ivey Business Journal Online, 72(1). Retrieved from http://iveybusinessjournal.com/publication/using-a-changemanagement-approach-to-implement-it-programs/

Hornstein, H. A. (2014). The integration of project management and organizational change management is now a necessity. International Journal of Project Management. Retrieved from http://dx.doi.org/10.1016/j.ijproman.2014.08.005

Hotek, D., \& White, M. (1999). An overview of performance technology. The Journal of Technology Studies, 25(1), 43-50.

Ibbs, C. W., Wong, C. K., \& Kwak, Y. H. (2001). Project change management system. Journal of Management in Engineering, 17(3), 159-165.

Indeje, W., \& Qin, Z. (2011). Stakeholder perception of information systems development success in the public sector. Management Science and Engineering, 5(2), 31-41.

Jääskeläinen, A., \& Sillanpää, V. (2013). Overcoming challenges in the implementation of performance measurement. The International Journal of Public Sector Management, 26(6), 440-454.

Karp, T., \& Helgø, T. I. T. (2008). From change management to change leadership: Embracing chaotic change in public service organizations. Journal of Change Management, 8(1), 85-96.

Kerzner, H. (2013). Project management: A systems approach to planning, scheduling, and controlling (11th ed.). Hoboken: John Wiley \& Sons.

Kickert, W. J. M. (2007). Public management reforms in countries with a Napoleonic state model: France, Italy and Spain. In C. Pollitt, S. van Thiel, \& V. Homburg (Eds.), The new public management in Europe: Adaptation and alternatives (pp. 26-51). Houndmills: Palgrave Macmillan. 
Kickert, W. J. M. (2010). Managing emergent and complex change: The case of the Dutch agencification. International Review of Administrative Sciences, 76(3), 489-515.

Kickert, W. J. M. (2013). Specificity of change management in public organizations: Conditions for successful organizational change in Dutch ministerial departments. The American Review of Public Administration. DOI: 10.11770275074013483871.

Klarner, P., Probst, G., \& Soparnot, R. (2008). Organizational change capacity in public services: The case of the World Health Organization. Journal of Change Management, 8(1), 57-72.

Kotter, J. P. (1995). Leading change: Why transformation efforts fail. Harvard Business Review, May-June, 59-67.

Kuipers, B. S., Higgs, M., Kickert, W. J. M., Tummers, L., Grandia, J., \& Van der Voet, J. (2014). Managing change in public organizations: A review of the literature between 2000-2010. Public Administration, 92(1), 1-20.

Leidecker, J. K., \& Bruno, A. V. (1984). Identifying and using critical success factors. Long Range Planning, 17, 23-32.

Lewin, K. (1947). Frontiers in group dynamics II. Channels of group life. Social planning and action research. Human Relations, 1(2), 143-153.

Loukis, E., \& Charalabidis, Y. (2011). Why do eGovernment projects fail? Risk factors of large information systems projects in the Greek public sector: An international comparison. International Journal of Electronic Government Research, 7(2), 59-77.

Momoh, A., Roy, R., \& Shehab, E. (2010). Challenges in enterprise resource planning implementation: State-of-the-art. Business Process Management Journal, 16(4), 537-565.

Nutt, P. C. (1992). Helping top management avoid failure during planned change. Human Resource Management 31(4), 319-344.

Ongaro, E. (2010). Public management reform and modernization: Trajectories of administrative change in Italy, France, Greece, Portugal and Spain. Northampton: Edward Elgar Publishing.

Palvia, S., \& Chervany, N. (1995). An experimental investigation of factors influencing predicted success in DSS implementation. Information \& Management, 29(1), 43-53.

PMI. (2013). A guide to the project management body of knowledge (5th ed.). Pennsylvania: Project Management Institute.

Pollitt, C., \& Bouckaert, G. (2011). Public management reform: A comparative analysis-new public management, governance, and the Neo-Weberian state. Oxford: Oxford University Press.

PWC. (2007). Insights and trends: Current programme and project management practices (1st ed.). London: Price Waterhouse Coopers. Retrieved from: http://www.pwc.com/en_US/us/peoplemanagement/assets/programme_project_management_survey.pdf

Ramaprasad, A., \& Williams, J. (1998). The utilization of critical success factors: A profile. Proceedings of the 29th Annual Meeting of the Decision Sciences Institute, LasVegas.

Rockart, J. F. (1979). Chief executives define their own data needs. Harvard Business Review, 57(2), $57-$ 81.

Rockart, J. F., \& Bullen, C. (1981). A primer on critical success factors. Center for Information Systems Research Working Paper No 69. Cambridge: Sloan School of Management, MIT.

Rothwell, W., \& Kazanas, H. (1998), Mastering the instructional design process: A systematic approach (2nd ed.). San Francisco: Jossey-Bass Publishers.

Rusaw, A. C. (2007). Changing public organizations: Four approaches. International Journal of Public Administration, 30(3), 347-361. 
Serra, C. E. M., \& Kunc, M. (2014). Benefits realisation management and its influence on project success and on the execution of business strategies. International Journal of Project Management, 33(1), 53 66.

Serrador, P. (2013). The impact of planning on project success: A literature review. Journal of Modern Project Management, 1(2), 28-39.

Smith, I. (2005). Continuing professional development and workplace learning 13: Resistance to changerecognition and response. Library Management, 26(8/9), 519-522.

Somers, T. M., \& Nelson, K. (2001). The impact of critical success factors across the stages of enterprise resource planning implementations. Proceedings of the 34th Annual Hawaii International Conference on System Sciences.

Stewart, J., \& Kringas, P. (2003). Change management-strategy and values in six agencies from the Australian public service. Public Administration Review, 63(6), 675-688.

Suman, N., Ursic, D., Psunder, M., \& Veselinovic, D. (2009). Mobile information and communication technology and management of business changes in construction companies in Slovenia. Systemic Practice and Action Research, 22(5), 397-411.

Sutanto, J., Kankanhalli, A., Tay, J., Raman, K. S., \& Tan, B. C. Y. (2008). Change management in interorganizational systems for the public. Journal of Management Information Systems, 25(3), 133-175.

Tan, V., \& Tan, N. T. (2005). Change management in times of economic uncertainty. Singapore Management Review, 27(1), 49-68.

The Economist. (2009). Closing the gap - The link between project management excellence and long-term success. London: The Economist Intelligence Unit.

Thomas, P. G. (1996). Beyond the buzzwords: Coping with change in the public sector. International Review of Administrative Sciences, 62(1), 5-29.

Turner, J. R. (2009). The handbook of project-based management - leading strategic change in organizations (3rd ed.). London: McGraw-Hill.

Turner, J. R., \& Müller, R. (2005). The project manager's leadership style as a success factor on projects: A literature review. Project Management Journal, 36(2), 49-61.

Umble J. E., Haft, R. R., \& Umble. M. M. (2003). Enterprise resource planning: Implementation procedures and critical success factors. European Journal of Operational Research, 146, 241-257.

Underwood-Stephens, C., \& Cobb, A. (1999). A Habermasian approach to justice in organizational change synthesizing the technical and philosophical perspectives. Journal of Organizational Change Management, 12(1), pp. 21-34.

Weber, P., \& Weber, J. (2001). Changes in employee perceptions during organizational change. Leadership \& Organizational Development Journal, 22(6), 291-300. 


\section{Biographies}

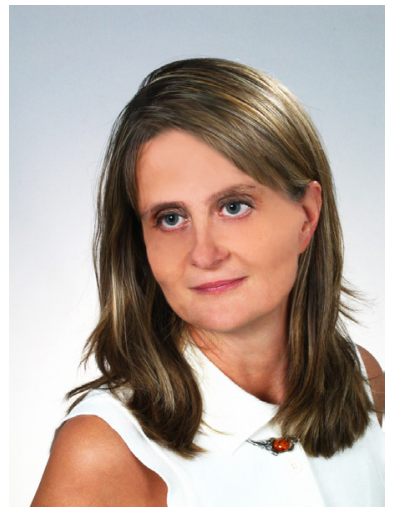

Ewa Ziemba (University of Economics in Katowice, Poland) completed her Ph.D. and Post Ph.D. in management, especially management information systems. She has vast experience in different areas of management information systems for business and public administration. She has published over 150 original papers in Polish and international peer-reviewed journals, and 11 books. Ewa Ziemba has played an instrumental role in different prestigious polish and international research projects. She is the member of several international scientific organizations, e.g. Informing Science Institute, International Association for Computer Information Systems, International Institute for Applied Knowledge Management, Association for Information Systems. She serves on the editorial board for several international journals. She is the editor-in-chief of The Online Journal of Applied Knowledge Management. In recognition in her outstanding teaching and research, Ewa Ziemba has been the recipient of numerous awards. She has received 14 awards of excellence from the Rector of University of Economics in Katowice, 'The Silver Cross of Merit' from President of Poland, 'The Medal of the National Education Commission' from Ministry of National Education in Poland, 'The Award of Fellow \& Distinguished Scholar' from International Institute for Applied Knowledge Management. Additionally, she has received three awards for the best papers at the international conferences.

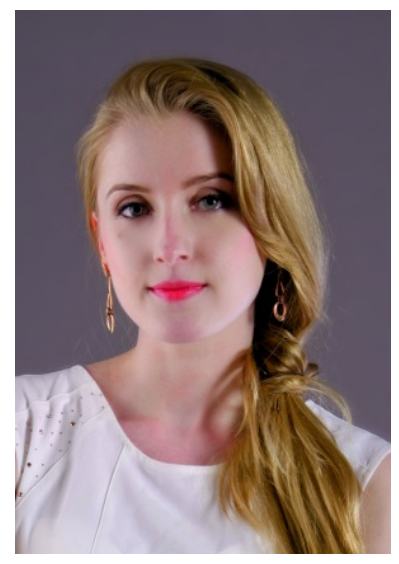

Iwona Obłąk is a Ph.D. candidate and doctoral research assistant at the University of Economics in Katowice (Poland). She is a PRINCE2 Practitioner certified IT Project Manager. She is experienced in information systems development and implementation. She provides project management services to business and government clients. She has also a background in business analysis. Her principal research areas are focused on project management, business process management, information systems in public and business sector, business process modeling and business analysis. She has received the awards for the best paper at the InSITE'2013 conference. 